\title{
PENGGUNAAN POLIETILEN GLIKOL SEBAGAI TEKNIK INVIGORASI UNTUK MEMPERBAIKI VIABILITAS, VIGOR, DAN PRODUKSI BENIH KEDELAI
}

\author{
ERNITA ERNITA ${ }^{1 *}$, FITRI MAIRIZKI ${ }^{2}$ \\ ${ }^{1,2}$ Program Studi Agroteknologi, Fakultas Pertanian, Universitas Islam Riau \\ Jl. Kaharuddin Nasution No.113, Pekanbaru \\ e-mail : ernitauir@agr.uir.ac.id
}

\begin{abstract}
ABSTRAK
Tujuan penelitian adalah untuk mendapatkan pengaruh kombinasi dan interaksi yang terbaik antara perlakuan konsentrasi dan lama perendaman polietileh glikol (PEG) terhadap viabilitas, vigor dan produksi benih kedelai. Penelitian dilakukan di Kebun Percobaan, Fakultas Pertanian, Universitas Islam Riau, dimulai pada bulan Desember 2015 sampai April 2016. Rancangan lingkungan yang digunakan adalah Rancangan Acak Lengkap Faktorial 4 x 4 dengan 3 ulangan. Faktor pertama adalah konsentrasi PEG terdiri atas 4 taraf : 0,0; 2,5; 5,0 dan 7,5\%. Faktor kedua adalah lama perendaman juga terdiri atas 4 taraf : 2; 4; 6 dan 8 jam. Parameter yang diamati yaitu daya kecambah, kecepatan tumbuh, indeks vigor, panjang plumule, panjang akar, jumlah polong berisi penuh dan bobot biji kering per tanaman. Hasil pengamatan dianalisis secara statistik dengan menggunakan analisis ragam dan diuji lanjut dengan menggunakan uji BNJ pada taraf 5\%. Hasil penelitian memperlihatkan bahwa konsentrasi PEG dan lama perendaman berpengaruh nyata terhadap daya kecambah, kecepatan tumbuh, indeks vigor, panjang plumule, panjang akar, jumlah polong berisi penuh dan bobot biji kering per tanaman. Kombinasi taraf faktor terbaik adalah konsentrasi PEG 7,5\% dan lama perendaman 6 jam.
\end{abstract}

Kata Kunci : Polietilen glikol, konsentrasi, perendaman, kedelai.

\begin{abstract}
The aim of the study was to obtain the best combination and interaction effects between the concentration treatment and the duration of soaking polyethylene glycol (PEG) on viability, vigor and soybean seed production. The study was conducted at the Experimental Garden, Faculty of Agriculture, Riau Islamic University, starting in December 2015 to April 2016. The environmental design used was a $4 \times 4$ Factorial Completely Randomized Design with 3 replications. The first factor is the PEG concentration consisting of 4 levels: $0.0 ; 2.5 ; 5.0$ and 7.5\%. The second factor is the soaking time also consists of 4 levels: 2; 4; 6 and 8 hours. The parameters observed were sprout power, growth speed, vigor index, plumule length, root length, the full number of pods and dry seed weight per plant. The observations were analyzed statistically using variance analysis and tested further using the BNJ test at the level of 5\%. The results showed that the PEG concentration and immersion time had a significant effect on germination, growth speed, vigor index, plumule length, root length, the full number of pods and dry seed weight per plant. The best combination of factor levels is $7.5 \%$ PEG concentration and 6 hours immersion time.
\end{abstract}

Keywords: Polyethylene glycol; concentration; submersion; soybean

Diterima: 20 Februari 2019, disetujui 12 April 2019 


\section{PENDAHULUAN}

Peningkatan permintaan akan kedelai (Glycine max L. Merril) setiap tahunnya menyebabkan kedelai menjadi komoditas tanaman pangan yang mempunyai potensi dan prospek yang cukup baik untuk dibudidayakan. Kedelai bersifat multi guna, selain dapat dikonsumsi secara langsung, kedelai juga dapat digunakan sebagai bahan baku agroindustri dan untuk keperluan industri serta pakan ternak. Gizi yang terkandung di dalam biji kedelai berupa protein sangat dibutuhkan untuk kesehatan tubuh manusia, harganya yang murah menjadikan kedelai menjadi pilihan utama dalam memenuhi protein tersebut.

Menurut Anonimus (2015), melaporkan bahwa terjadi peningkatan sebesar 175.010 ton atau setara dengan $22.44 \%$ pada tahun 2014 dibandingkan produksi pada tahun 2013. Pada tahun 2015 terjadi peningkatan produksi sebesar $4.50 \%$. peningkatan produksi kedelai terjadi sejalan dengan perluasan areal panen menjadi $4.670 \mathrm{Ha}$ setara dengan $4.01 \%$, sehingga produktivitas menjadi 0.09 kwintal hektar ${ }^{-1}$. Pertambahan jumlah penduduk merupakan salah satu factor yang menyebabkan bertambahnya kebutuhan kedelai, sehingga produksi kedelai juga harus ditingkatkan. Salah satu solusi yang dapat dilaksanakan dalam meningkatkan produksi kedelai ini adalah dengan ektensifikasi, menghasilkan varietas bermutu, dan ntensifikasi dengan menanam varietas unggul. Hal penting yang perlu diperhatikan dalam menjaga kesinambungan produksi tanaman adalah ketersediaan benih bermutu. Bila benih yang digunakan bermutu rendah maka akibatnya produksi akan rendah, penyebabnya antara lain kemampuan berdaptasi benih terhadap lingkungan yang beragam juga akan rendah.

Pada daerah tropis, deteriorasi benih kedelai akan cepat terjadi. Penyebabnya adalah karena kandungan protein biji kedelai yang tinggi, sehingga benih banyak mengabsorbsi air yang berakibat terhadap naiknya kadar air benih.

Kemunduran dapat terjadi selama periode penyimpanan dan lebih cepat terjadi bila kondisi penyimpanan kurang optimum. Biji kedelai yang disimpan di dalam gudang yang tidak berpendingin akan cepat mengalami kemunduran, dan benih tersebut hanya mampu bertahan 3-5 bulan, bahkan bila lebih dari 6 bulan maka benih banyak yang tidak tumbuh. Selain itu, jalur distribusi benih yang panjang dan memakan waktu yang lama dapat menyebabkan turunnya viabilitas dan vigor benih yang sampai ke petani.

Menurut Rusmin (2007), menjelaskan bahwa invigorasi dapat dilakukan untuk mengatasi benih yang sudah mengalami kemunduran, berdasarkan penelitian yang dilakukan bahwa invigorasi dapat meningkatkan viabilitas benih 10\%-20\%. Surtinah (2018) melaporkan bahwa invigorasi pada benih seledri dengan menggunakan Gibgrow pada air perendaman, dan direndam selama 24 jam dapat meningkatkan perkecambahan benih seledri lebih banyak dibandingkan dengan perlakuan yang lainnya.

Salah satu teknik invirogasi adalah dengan osmoconditioning yaitu mengkondisikan benih dalam larutan osmotikum. Tujuan osmoconditioning 
untuk mempercepat perkecambahan, menyerempakkan, meningkatkan persentase perkecambahan dan pertumbuhan di lapangan. Osmoconditioning dapat menggunakan garam seperti natrium klorida $(\mathrm{NaCl})$, kalium nitrat $\left(\mathrm{KNO}_{3}\right)$ dan polietilen glikol (PEG). Girolamo and Barbanti (2012) melaporkan bahwa larutan osmoconditioning dengan besar molekul 6000 atau 8000 dapat digunakan krena tidak menembus jaringan yang ada di dalam benih contohnya seperti larutan PEG.

PEG yang digunakan diberbagai penelitian benih sangat berperan dalam meningkatkan viabilitas dan waktu yang digunakan untuk proses perkecambahan menjadi lebih cepat. Dan senyawa PEG ini sudah digunakan pada benih tanaman pangan dan hortikultura. Hasil penelitian yang dilakukan oleh Arief, Tariq, Khan,

\section{METODE PENELITIAN}

Penelitian dilaksanakan di Kebun Percobaan Fakultas Pertanian, Universitas Islam Riau, selama 5 bulan dari bulan Desember 2015 sampai dengan bulan April 2016.

Bahan yang digunakan dalam penelitian adalah benih kacang kedelai varietas Dering 1 polibag, akuades, polietilen glikol 6000 (PEG), furadan 3G, pupuk NPK grower, dithane M-45, decis 25 EC, pupuk kandang ayam, dolomite, cat minyak, dan seng plat. Adapun peralatan yang digunakan dalam penelitian adalah cangkul, parang, gelas ukur, timbangan analitik, moisture tester, gelas plastik, rak plastik, hand sprayer, gembor, penggaris, meteran, tali rafia, alat tulis dan kamera. dan Munir ( 2011) menjelaskan bahwa pada konsentrasi 100-300 g $\operatorname{liter}^{-1}$ air senyawa PEG mampu menaikkan bobot kering tanaman dan kecepatan nisbi pertumbuhan tanaman kedelai.

Hasil penelitian lain memperlihatkan bahwa perendaman benih kedelai selama 6 jam dengan larutan PEG dapat meningkatkan kecepatan tumbuh dan vigor benih. Namun penelitian penggunaan PEG terhadap benih kedelai yang telah menurun mutunya belum banyak dilaporkan. Oleh karena itu, perlu dilakukan penelitian yang mengkombinasikan konsentrasi dan lama perendaman benih kedelai dengan larutan PEG dengan tujuan untuk mengetahui pengaruh interaksi dan masing-masing faktor utama terhadap viabilitas, vigor dan produksi benih kedelai.

Rancangan percobaan ini menggunakan Rancangan Acak Lengkap (RAL) faktorial $4 \times 4$ dengan 3 ulangan. Faktor pertama adalah konsentrasi PEG (K), terdiri dari 4 taraf : 0,0 (tanpa PEG); 2,5; 5,0 dan 7,5\% sedangkan faktor kedua adalah lama perendaman PEG (L), terdiri dari 4 taraf : 2, 4, 6 dan 8 jam. Pada setiap satuan percobaan terdapat 15 tanaman dan 3 tanaman dijadikan sampel. Pada pengamatan perkecambahan, masingmasing satuan unit percobaan terdiri dari 10 polibag (kecambah) dan 3 kecambah sebagai sampel. Hasil pengamatan dianalisis secara statistik dan bila berpengaruh nyata maka diadakan uji lanjut Beda Nyata Jujur (BNJ) pada taraf $5 \%$. 
Pengamatan dilakukan terhadap parameter : daya kecambah benih (\%), kecepatan tumbuh kecambah $\left(\%\right.$ peretmal $^{-}$ ${ }^{1}$ ), indeks vigor perkecambahan, panjang plumule $(\mathrm{cm})$, panjang akar $(\mathrm{cm})$, jumlah polong berisi penuh pertanaman (buah) dan bobot kering biji pertanaman (g). Panen kedelai dilakukan ketika tanaman

\section{HASIL DAN PEMBAHASAN}

\section{Daya Kecambah (\%)}

Hasil sidik ragam terhadap daya kecambah dipengaruhi oleh kombinasi perlakuan antara konsentrasi PEG dan lama perendaman. Dan PEG sebagai sudah memenuhi kreteria panen seperti polong berwarna kuning kecoklatan secara merata, daun sudah kering dan rontok serta batang mulai mengering. Panen dilakukan pada pagi hari

Tabel 1. Rata-Rata Daya Kecambah Benih Kedelai dengan Penggunaan Konsentrasi dan Lama Perendaman Polietilen Glikol (\%)

\begin{tabular}{|c|c|c|c|c|c|}
\hline \multirow{2}{*}{$\begin{array}{l}\text { Konsentrasi } \\
\text { PEG }(\%)\end{array}$} & \multicolumn{4}{|c|}{ Lama Perendaman (jam) } & \multirow{2}{*}{ Rerata } \\
\hline & L1 (2) & L2(4) & L3 (6) & L4 (8) & \\
\hline $\mathrm{K} 0(0)$ & $43,33 \mathrm{abc}$ & $46,67 \mathrm{abc}$ & $30,00 \mathrm{c}$ & $36,67 \mathrm{bc}$ & $39,17 \mathrm{~b}$ \\
\hline $\mathrm{K} 1(2,5)$ & $46,67 \mathrm{abc}$ & $53,33 \mathrm{ab}$ & $60,00 \mathrm{a}$ & $46,67 \mathrm{abc}$ & $51,67 \mathrm{a}$ \\
\hline $\mathrm{K} 2(5,0)$ & $56,67 \mathrm{ab}$ & $60,00 \mathrm{a}$ & $43,33 \mathrm{abc}$ & $53,33 \mathrm{ab}$ & $53,33 \mathrm{a}$ \\
\hline K3 $(7,5)$ & $46,67 \mathrm{abc}$ & $46,67 \mathrm{abc}$ & $46,67 \mathrm{abc}$ & $63,33 \mathrm{a}$ & $50,83 \mathrm{a}$ \\
\hline Rerata & 48,33 & 51,67 & 45,00 & 50,00 & \\
\hline $\mathrm{KK}=13,88 \%$ & $\mathrm{BNJ} \mathrm{KL}=20,52$ & $\mathrm{BN}$ & $=7,48$ & & \\
\hline
\end{tabular}

Angka-angka pada kolom dan baris yang diikuti huruf kecil yang sama tidak berbeda nyata menurut uji BNJ taraf $5 \%$.

Tabel 1 menunjukkan bahwa kombinasi taraf faktor K3L4, K1L3 dan K2L2 menghasilkan daya kecambah tertinggi walaupun tidak berbeda nyata dengan kombinasi taraf faktor lainnya kecuali dengan kombinasi taraf faktor K0L4 dan K0L3 yang menghasilkan persentase kecambah terendah sebesar $30,00 \%$.

Adanya kecendrungan terbaik kosentrasi PEG 7,5\% dan lama $\begin{array}{lllll}\text { perendaman } & 8 & \text { jam } & \text { (K3L4) yang }\end{array}$ menghasilkan persentase kecambah tertinggi sebesar 63,33\% disebabkan peran PEG-6000 sebagai bahan factor utama mempengaruhi daya berkecambah biji kedelai. Hasil uji beda rata-rata perlakuan dengan $\mathrm{BNJ}$ pada $\mathrm{p}$ 0.05 ditampilkan pada Tabel 1 . osmoconditioning dapat meningkatkan kemampuan benih untuk berkecambah. Penggunaan PEG-6000 ternyata dapat menekan laju imbibisi benih perendaman benih selama 8 jam (L4) adalah lama perendaman yang paling efektif, sehingga benih dapat melakukan metabolismenya dengan optimal pada fase II dalam system perkembangan biji.

Kombinasi taraf faktor tanpa PEG dengan lama perendaman 6 jam (K0L3) menghasilkan daya kecambah terendah dengan persentase $30 \%$, tidak berbeda dengan kombinasi taraf faktor pada K0L4 yang menghasilkan kecambah 36,67\%. 
Hal ini disebabkan benih direndam lebih lama sehingga benih menyerap air lebih banyak. Penyerapan air yang banyak dapat mengurangi oksigen yang diperlukan dalam respirasi benih sehingga menghambat perkecambahan.

Ruliyansyah (2010) menyatakan bahwa oksigen sangat diperlukan dalam respirasi khususnya dalam proses katabolisme yang akan menghasilkan energy untuk digunakan dalam proses perkecambahan. Nurmauli dan Nurmiaty (2010) berpendapat bahwa penyerapan air yang berlebihan oleh sel dan jaringan benih berakibat pada terhambatnya proses perkecambahan. Proses perendaman biji dapat meningkatkan turgor yang dapat menyebabkan kulit benih pecah, akibatnya membrane sel tidak dapat mengendalikan proses imbibisi.

\section{Kecepatan Tumbuh (\% peretmal $\left.^{-1}\right)$}

Hasil pengamatan kecepatan tumbuh benih kedelai dan factor utama konsentrasi PEG berpengaruh nyata sedangkan lama perendaman tidak berpengaruh nyata terhadap kecepatan tumbuh benih kedelai berdasarkan hasil sidik ragam. Uji beda rata-rata perlakuan BNJ taraf 5\% tercantum pada Tabel 2 .

Tabel 2. Rata-Rata Kecepatan Tumbuh Perkecambahan Kedelai dengan Penggunaan Konsentrasi dan Lama Perendaman Polietilen Glikol (\% per etmal ${ }^{-1}$ )

\begin{tabular}{llllll}
\hline Konsentrasi PEG & \multicolumn{5}{c}{ Lama Perendaman (jam) } \\
\cline { 2 - 5 }$(\%)$ & L1 $(2)$ & L2(4) & L3 $(6)$ & L4 $(8)$ & \\
\hline K0 $(0)$ & $6,19 \mathrm{abc}$ & $6,66 \mathrm{abc}$ & $4,79 \mathrm{c}$ & $5,74 \mathrm{bc}$ & $5,59 \mathrm{~b}$ \\
K1 $(2,5)$ & $6,66 \mathrm{abc}$ & $7,62 \mathrm{ab}$ & $8,57 \mathrm{a}$ & $6,66 \mathrm{abc}$ & $7,38 \mathrm{a}$ \\
K2 $(5,0)$ & $8,09 \mathrm{ab}$ & $8,57 \mathrm{a}$ & $6,19 \mathrm{abc}$ & $7,62 \mathrm{ab}$ & $7,62 \mathrm{a}$ \\
$\mathrm{K} 3(7,5)$ & $6,66 \mathrm{abc}$ & $6,66 \mathrm{abc}$ & $6,66 \mathrm{abc}$ & $9,05 \mathrm{a}$ & $7,62 \mathrm{a}$ \\
\hline Rerata & 6,90 & 7,38 & 6,43 & 7,14 & \\
\hline KK= 13,85\% BNJ KL $=2,92 \mathrm{BNJ} \mathrm{K}=1,06$ & & & \\
\hline
\end{tabular}

Angka-angka pada kolom dan baris yang diikuti huruf kecil yang sama tidak berbeda nyata menurut uji BNJ taraf 5\%.

Tabel 2 menunjukkan bahwa kombinasi taraf factor K3L4 ada kecendrungan merupakan terbaik yang menghasilkan kecepatan berkecambah tertinggi yaitu $9,05 \%$ peretmal $^{-1}$ tidak berbeda nyata dengan kombinasi taraf faktor K1L3 dan K2L2 dan kombinasi taraf faktor lainnya kecuali dengan kombinasi taraf faktor K0L4 dan K0L3 yang menghasilkan kecepatan tumbuh terendah $4,79 \%$ peretmal $^{-1}$.

Hal ini membuktikan PEG dengan konsentrasi 2,5\% dengan lama perendaman 6 jam (K1L3) sudah mampu meningkatkan kecepatan tumbuh kecambah dengan nilai $8,57 \%$ per etmal 1. Pada konsentrasi 2,5\% - 7,5\% tersebut PEG dapat memperbaiki proses metabolime di dalam perkecambahan sehingga energi yang dihasilkan untuk perkecambahan meningkat dan pembentukan struktur kecambah pun lebih cepat. Kecepatan perkecambahan mencerminkan metabolisma yang terjadi selama proses perkecambahan berlangsung optimal.

Imbibisi merupakan awal dari perkecambahan benih, Girolamo dan Barbanti (2012), imbibisi yang dilakukan benih terjadi dalam tiga fase. Pada Fase I, 
kecepatan penyerapan air sangat cepat disebabkan karena adanya perbedaan potensial air dan potensial benih. Pada Fase II imbibisi berjalan lambat karena di dalam benih sudah terjadi keseimbangan potensial air pada benih dengan lingkungannya. Fase III imbibisi kecepatannya meningkat disebabkan karena pertumbuhan dan perkembangan kecambah sedang berlangsung yang diawali dengan munculnya radikula.

Osmoconditioning menyebabkan rendahnya potensial air benih sehingga penyerapan air pada fase I menjadi lambat. Pada benih yang sudah mengalami deteriorasi fase II dapat diperanjang, kondisi dibutuhkan oleh benih untuk mengorganisir proses metabolismenya sebelum masuk ke fase III Sivasubramaniam et al. (2011).

\section{Indeks Vigor Perkecambahan}

Pengamatan terhadap indeks vigor kecambah kedelai berdasarkan sidik ragam terjadi interaksi dan factor utama konsentrasi PEG berpengaruh nyata. Data hasil uji beda rata-rata perlakuan BNJ pada taraf 5\% terdapat pada Tabel 3 .

Tabel 3. Rata-Rata Indeks Vigor Perkecambahan Kedelai dengan PenggunaanKonsentrasi dan Lama Perendaman Polietilen Glikol

\begin{tabular}{llllll}
\hline \multirow{2}{*}{ Konsentrasi PEG $(\%)$} & \multicolumn{5}{c}{ Lama Perendaman (jam) } \\
\cline { 2 - 5 } & L1 $(2)$ & L2(4) & L3 $(6)$ & L4 $(8)$ \\
\hline K0 ( 0) & $0,87 \mathrm{abc}$ & $0,91 \mathrm{abc}$ & $0,57 \mathrm{c}$ & $0,76 \mathrm{bc}$ & $0,78 \mathrm{~b}$ \\
$\mathrm{~K} 1(2,5)$ & $0,91 \mathrm{abc}$ & $1,01 \mathrm{ab}$ & $1,16 \mathrm{a}$ & $0,93 \mathrm{abc}$ & $1,00 \mathrm{a}$ \\
$\mathrm{K} 2(5,0)$ & $1,07 \mathrm{ab}$ & $1,08 \mathrm{ab}$ & $0,88 \mathrm{abc}$ & $0,99 \mathrm{ab}$ & $1,00 \mathrm{a}$ \\
$\mathrm{K} 3(7,5)$ & $0,89 \mathrm{abc}$ & $0,94 \mathrm{abc}$ & $0,86 \mathrm{abc}$ & $1,12 \mathrm{ab}$ & $0,95 \mathrm{a}$ \\
\hline Rerata & 0,93 & 0,99 & 0,87 & 0,95 & \\
\hline KK= 13,16\% BNJ KL = 0,37 & BNJ K = 0,13 & & & \\
\hline
\end{tabular}

Angka-angka pada kolom dan baris yang diikuti huruf kecil yang sama tidak berbeda nyata menurut uji BNJ taraf $5 \%$.

Tabel 3 menunjukkan kombinasi taraf faktor pada K1L3 menghasilkan indeks vigor yang tertinggi tetapi tidak berbeda nyata dengan kombinasi taraf faktor lainnya kecuali dengan kombinasi taraf factor K0L4 dan K0L3 yang menghasilkan indeks perkecambahan yang terendah tetapi K0L4 tidak berbeda nyata dengan K0L3. .

Kombinasi taraf faktor konsentrasi PEG 2,5\% dengan lama perendaman 6 jam (K1L3) menghasilkan indeks vigor perkecambahan 1,16. Hal ini terjadi disebabkan peranan PEG-6000 sebagai bahan osmoconditioning benih kedelai yang mengalami kemunduran pada konsentrasi tersebut dapat meningkatkan kemampuan benih untuk berkecambah dan waktu terbaik untuk meningkatkan indeks vigor perkecambahan adalah dengan merendam benih selama 6 jam. Akan tetapi, kombinasi taraf faktor tanpa penggunaan PEG dengan perendaman benih selama 6 jam (K0L3) menghasilkan indeks vigor perkecambahan terendah yaitu 0,57 dan tidak berbeda dengan kombinasi taraf faktor pada K0L4 dengan indeks vigor perkecambahan yang dihasilkan 0,76.

Nilai indeks vigor berkaitan dengan kecepatan benih berkecambah. Kecepatan perkecambahan mengidentifikasikan 
bahwa benih vigor. Perendaman benih dalam air dan perlakuan osmotikum sebenarnya adalah salah satu upaya yang dilakukan untuk mempercepat perkecambahan benih, proses imbibisi yang cepat berakibat pada seluruh proses metabolisme, asimilasi, reaksi biokimia yang terjadi di dalam benih akan lebih cepat, yang akan memacu munculnya radikula lebih cepat pula.

\section{Panjang Plumule (cm)}

Panjang plumule kecambah kedelai berdasarkan sidik ragam ber pengaruh interaksi dan utama konsentrasi PEG nyata terhadap panjang plumule kecambah kedelai. Hasil uji beda rata-rata peerlakuan BNJ pada taraf 5\% dapat dilihat pada Tabel 4.

Tabel 4. Rata-Rata Panjang Plumule dengan Penggunaan Konsentrasi dan Lama PerendamanPolietilen Glikol (cm) .

\begin{tabular}{|c|c|c|c|c|c|}
\hline \multirow{2}{*}{$\begin{array}{l}\text { K KK Konsentrasi } \\
\text { PEG }(\%)\end{array}$} & \multicolumn{4}{|c|}{ Lama Perendaman (jam) } & \multirow{2}{*}{ Rerata } \\
\hline & L1 (2) & L2(4) & L3 (6) & L4 (8) & \\
\hline K0 ( 0) & $1,13 \mathrm{ghi}$ & $1,07 \mathrm{hi}$ & $1,03 \mathrm{i}$ & $1,10 \mathrm{ghi}$ & $1,08 \mathrm{c}$ \\
\hline $\mathrm{K} 1(2,5)$ & $1,30 \mathrm{def}$ & $1,23 \mathrm{efg}$ & $1,17 \mathrm{fgh}$ & $1,13 \mathrm{ghi}$ & $1,21 \mathrm{~b}$ \\
\hline $\mathrm{K} 2(5,0)$ & $1,33 \mathrm{de}$ & $1,47 \mathrm{c}$ & $1,40 \mathrm{~cd}$ & $1,67 \mathrm{ab}$ & $1,47 \mathrm{a}$ \\
\hline $\mathrm{K} 3(7,5)$ & 1,27 def & 1,33 de & $1,63 \mathrm{~b}$ & $1,77 \mathrm{a}$ & $1,50 \mathrm{a}$ \\
\hline Rerata & $1,26 \mathrm{c}$ & $1,28 \mathrm{c}$ & $1,31 \mathrm{~b}$ & $1,42 \mathrm{a}$ & \\
\hline
\end{tabular}

Angka-angka pada kolom dan baris yang diikuti huruf kecil yang sama tidak berbeda nyata menurut uji BNJ taraf 5\%.

Kombinasi taraf faktor K3L4 interaksi konsentrasi dan lama menghasilkan panjang plumule yang perendaman PEG tidak nyata akan tetapi tertinggi tetapi tidak berbeda nyata pengaruh utama konsentrasi Polietilen dengan K2L4, dan panjang plumule Glikol nyata terhadap panjang akar terendah terdapat pada perlakuan tanpa kecambah kedelai. Data hasil uji lanjut penggunaan PEG. Hal ini disebabkan pada konsentrasi PEG 5,0 \% sudah dapat mengurangi nilai potensial lingkungan benih pada fase I pada saat terjadi imbibisi. Benih yang direndam 8 jam diduga mampu melakukan metabolismenya sapai akhir fase II, sehingga pada fase III benih berkecambah dengan munculnya radikula dan plumula.

\section{Panjang Akar (cm)}

Hasil pengamatan panjang akar kecambah kedelai setelah dianalisis sidik ragam menunjukkan bahwa pengaruh BNJ pada taraf 5\% dapat dilihat pada Tabel 5.

PEG yang digunakan dapat meningkatkan panjang akar dan berbeda nyata pengaruhnya dengan tanpa penggunaan PEG. Perendaman benih bertujuan untuk mempercepat proses perkecambahan bila perkecambahan dapat dipercepat maka proses pertumbuhan dan perkembangan tanaman akan cepat juga, seperti translokasi nutrisi dan keluarnya radikel terjadi lebih cepat. Keluarnya radikel yang lebih cepat juga akan dapat menyebabkan pertumbuhan akar lebih cepat dan lebih panjang 
Tabel 5. Rata-Rata Panjang Akar dengan Penggunaan Konsentrasi dan Lama Perendaman Polietilen Glikol (cm)

\begin{tabular}{|c|c|c|c|c|c|}
\hline \multirow{2}{*}{ Konsentrasi PEG (\%) } & \multicolumn{4}{|c|}{ Lama Perendaman (jam) } & \multirow{2}{*}{ Rerata } \\
\hline & L1 (2) & L2(4) & L3 (6) & L4 (8) & \\
\hline K0 ( 0) & 5,57 & 5,13 & 5,03 & 5,03 & $5,19 \mathrm{~b}$ \\
\hline $\mathrm{K} 1(2,5)$ & 5,93 & 6,13 & 6,90 & 7,40 & $6,59 \mathrm{a}$ \\
\hline $\mathrm{K} 2(5,0)$ & 6,97 & 6,43 & 6,67 & 7,50 & $6,92 \mathrm{a}$ \\
\hline $\mathrm{K} 3(7,5)$ & 6,73 & 8,07 & 6,77 & 8,60 & $7,54 \mathrm{a}$ \\
\hline Rerata & 6,30 & 6,44 & 6,34 & 7,16 & \\
\hline \multicolumn{6}{|c|}{$\mathrm{KK}=14.70 \% \quad \mathrm{BNJ} \mathrm{K}=1,06$} \\
\hline
\end{tabular}

\section{Jumlah Polong Berisi Penuh \\ Pertanaman (polong)}

Konsentrasi dan lama PEG polong berisi pertanaman. Hasil uji beda berpengaruh nyata terhadap jumlah rata-rata perlakuan disajikan pada Tabel 6.

Tabel 6. Rata-Rata Jumlah Polong Berisi Penuh Pertanaman dengan Penggunaan dan Lama Perendaman Polietilen Glikol (buah)

\begin{tabular}{|c|c|c|c|c|c|}
\hline \multirow{2}{*}{$\begin{array}{l}\text { Konsentrasi PEG } \\
(\%)\end{array}$} & \multicolumn{4}{|c|}{ Lama Perendaman (jam) } & \multirow{2}{*}{ Rerata } \\
\hline & L1 (2) & L2(4) & L3 (6) & L4 (8) & \\
\hline K0 $(0,0)$ & 55,67 cdef & $41,56 \mathrm{f}$ & $18,78 \mathrm{~g}$ & 65,78 abcd & $45,45 \mathrm{c}$ \\
\hline $\mathrm{K} 1(2,5)$ & $67,00 \mathrm{abcd}$ & $52,22 \mathrm{def}$ & 48,45 ef & 45,11 ef & $53,19 \mathrm{~b}$ \\
\hline $\mathrm{K} 2(5,0)$ & 59,00 bcde & 60,22 bcde & $67,22 \mathrm{abcd}$ & $72,56 \mathrm{ab}$ & $64,75 \mathrm{a}$ \\
\hline K3 $(7,5)$ & $55,78 \mathrm{cdef}$ & $70,89 \mathrm{abc}$ & $78,56 \mathrm{a}$ & $69,11 \mathrm{abc}$ & $68,58 \mathrm{a}$ \\
\hline Rerata & $59,36 \mathrm{ab}$ & $56,22 \mathrm{~b}$ & $56,22 \mathrm{~b}$ & $63,14 \mathrm{a}$ & \\
\hline \multicolumn{2}{|c|}{$\mathrm{KK}=9,12 \% \mathrm{BNJ} \mathrm{KL}=16,05$} & \multicolumn{3}{|c|}{ BNJ $\mathrm{K}$ dan $\mathrm{L}=5,85$} & \\
\hline
\end{tabular}

Angka-angka pada kolom dan baris yang diikuti huruf kecil yang sama tidak berbeda nyata menurut uji BNJ taraf 5\%.

Kombinasi K3L3 menghasilkan jumlah polong berisi penuh pertanaman tertinggi yaitu 78,56 buah walaupun tidak berbeda nyata dengan kombinasi taraf faktor K1L1, K2L3, K2L4, K3L4 dan K0L4. Jumlah polong berisi penuh terendah pada kombinasi taraf faktor tanpa menggunakan PEG dan durasi perendaman selama 6 jam (K0L3).

Jumlah polong berisi erat hubungan dengan faktor intern dari tanaman kedelai itu sendiri. Selain itu, polong berisi juga dipengaruhi oleh proses pembungaan, pembentukan polong dan proses metabolisme pemasakan polong serta ada tidaknya kehadiran hama seperti hama penghisap polong. Menurut Padjar (2010), melaporkan bahwa 7-10 hari sejak bunga pertama muncul polong kedelai mulai terbentuk yang panjangnya lebih kurang 1 $\mathrm{cm}$, polong terbentuk pada disetiap ketiak daun yang jumlahnya berkisar antara 1-10 per kelompok, dalam satu tanaman polong yang terbentuk 50 bahkan bias lebih dari itu.

Konsentrasi PEG memberikan hasil yang lebih baik jika dibandingkan tanpa menggunakan PEG. Konsentrasi PEG $7,5 \%$ menghasilkan rata-rata jumlah polong berisi penuh terbanyak yaitu 68,58 buah. Namun, tidak berbeda dengan konsentrasi $5 \%$ yang menghasilkan 
jumlah polong berisi penuh sebanyak 64,75 buah dengan selisih polong keduanya sebesar 3,83 buah. Lama perendaman PEG 8 jam menghasilkan jumlah polong berisi penuh terbanyak yaitu 63,14 buah berbeda dengan perlakuan lainnya..

Menurut Munawar (2010), indikator berisi penuh atau tidaknya buah dan biji dilakukan dengan pengamatan bentuk buah dan biji. Bentuk buah dan biji yang padat berisi merupakan hasil dari penimbunan asimilat dari daun ke buah dan biji. Pemenuhan hara dapat menyebabkan buah dan biji tanaman akan memiliki bentuk padat dan berisi sehingga bobot biji dan buah akan tinggi.
Ketidakseimbangan asupan asimilat dengan jumlah polong yang dihasilkan oleh tanaman akan menurunkan persentase polong berisi penuh pada tanaman kedelai.

\section{Bobot Kering Biji Pertanaman (Gram)}

Berat kering biji pertanaman kedelai setelah dianalisis sidik ragam menunjukkan bahwa interaksi dan masing-masing perlakuan utama konsentrasi dan lama perendaman PEG berpengaruh nyata terhadap bobot kering biji pertanaman kedelai. Data hasil uji beda rata-rata perlakuan BNJ dapat dilihat pada Tabel 7.

Tabel 7. Rata-Rata Bobot Kering Biji Pertanaman Kedelai dengan Penggunaan Beberapa Konsentrasi dan Lama Perendaman Polietilen Glikol (gram).

\begin{tabular}{llllll}
\hline \multirow{2}{*}{ Konsentrasi PEG (\%) } & \multicolumn{5}{c}{ Lama Perendaman (jam) } \\
\cline { 2 - 6 } & L1 (2) & L2(4) & L3 (6) & L4 (8) & \\
\hline K0 $(0,0)$ & $18,84 \mathrm{de}$ & $16,21 \mathrm{e}$ & $13,15 \mathrm{e}$ & $28,00 \mathrm{bcd}$ & $19,05 \mathrm{c}$ \\
K1 $(2,5)$ & $28,77 \mathrm{bc}$ & $15,74 \mathrm{e}$ & $28,15 \mathrm{bcd}$ & $21,44 \mathrm{cde}$ & $23,53 \mathrm{~b}$ \\
K2 $(5,0)$ & $27,69 \mathrm{bcd}$ & $20,29 \mathrm{cde}$ & $35,70 \mathrm{ab}$ & $36,29 \mathrm{ab}$ & $30,00 \mathrm{a}$ \\
K3 $(7,5)$ & $22,07 \mathrm{cde}$ & $28,92 \mathrm{bc}$ & $44,01 \mathrm{a}$ & $28,77 \mathrm{bc}$ & $30,94 \mathrm{a}$ \\
\hline Rerata & $24,34 \mathrm{~b}$ & $20,29 \mathrm{c}$ & $30,25 \mathrm{a}$ & $28,63 \mathrm{a}$ & \\
\hline KK $=12,05 \%$ & BNJ & BN $=9,45$ & & &
\end{tabular}

KK= $12,05 \% \quad$ BNJ KL $=9,45 \quad$ BNJ K dan $\mathrm{L}=3,45$

Angka-angka pada kolom dan baris yang diikuti huruf kecil yang sama tidak berbeda nyata menurut uji BNJ taraf 5\%.

$\begin{array}{llll}\text { Kombinasi perlakuan } & \text { K3L3 } & \text { Penggunaan PEG dengan konsentrasi dan } \\ \text { menghasilkan bobot biji kering } & \text { lama perendaman yang tepat dapat } \\ \text { pertanaman tertinggi yaitu 44,01 gram } & \text { menghasilkan benih yang vigor } \\ \text { tetapi tidak berbeda nyata dengan } & \text { dicerminkan dengan kecepatan dan } \\ \text { kombinasi taraf faktor K2L3 dan K2L4, } & \text { keserempakan tumbuh. Benih yang vigor } \\ \text { sedangkan perlakuan yang menghasilkan } & \text { akan berpengaruh terhadap pertumbuhan } \\ \text { bobot biji kering terendah pada kombinasi } & \text { dan perkembangan tanaman di lapangan, } \\ \text { taraf faktor K0L3 sebesar 13,15 gram. } & \text { dan akan menghasikan tanaman yang } \\ \text { Lebih tingginya bobot biji kering tertinggi } & \text { vigor juga yang memiliki daya adaptasi } \\ \text { pada K3L3 disebabkan konsentrasi PEG } & \text { yang luas terhadap lingkungan yang } \\ \text { 7,5\% dan durasi } 6 \text { jam benih direndam } & \text { menekan, sehingga produksi tanaman } \\ \text { merupakan kombinasi yang paling efektif } & \text { akan meningkat. Produksi tanaman } \\ \text { menstimulir produksi kedelai. } & \text { kedelai pada kombinasi taraf faktor K3L3 }\end{array}$


mencapai 5,5 ton jauh dibandingkan dengan potensi produksi yang hanya 2,83 ton perhektar.

Konsentrasi PEG yang menghasilkan rata-rata terbaik yaitu dengan konsentrasi 7,5\% dengan rata-rata 30,94 gram tetapi tidak berbeda nyata dengan konsentrasi $5 \%$ yang menghasilkan rata-rata bobot kering biji tanaman sebesar 30,00 gram, dimana hanya berselisih 0,94 gram. Lama perendaman PEG yang terbaik yaitu dengan waktu 6 jam (L3) menghasilkan rata-rata hasil bobot kering biji pertanaman sebesar 30,25 gram tidak berbeda nyata dengan perlakuan 8 jam (L4).

\section{KESIMPULAN}

Interaksi penggunaan konsentrasi dan lama perendaman PEG memberikan pengaruh nyata terhadap daya kecambah, kecepatan tumbuh, indeks vigor, panjang plumule, panjang akar, jumlah polong berisi penuh dan bobot biji kering pertanaman. Kombinasi antara perlakuan PEG 7,5\% dengan lama perendaman 6 jam (K3L3) Pengaruh utama konsentrasi PEG nyata terhadap persentase perkecambahan, kecepatan tumbuh,

\section{UCAPAN TERIMA KASIH}

Ucapan terima kasih disampaikan kepada Bapak Rektor Universitas Islam Riau, Pekanbaru yang telah memberi bantuan dana penelitian melalui Lembaga Penenelitian UIR. Ucapan terima kasih
Menurut Zulkarnaeni (2010), Produktivitas tiap tumbuhan yang tinggi akan menyebabkan tingginya hasil produksi tumbuhan tersebut. Pembentukan jaringan tanaman membutuhkan unsur hara yang cukup, dan seimbang sehingga pertumbuhan tanaman dapat optimal yang akan menghasilkan produksi yang optimal juga, terutama pada waktu pembentukan buah, dan peningkatan berat buah. Unsur hara menjadi energi untuk menstimulus peningkatan pertumbuhan dan perkembangan serta hasil produksi tanaman.

indeks vigor, panjang plumule dan panjang akar, jumlah polong berisi penuh dan bobot biji kering pertanaman. Perlakuan konsentrasi PEG terbaik adalah $7,5 \%$ (K3). Pengaruh utama lama perendaman PEG nyata terhadap panjang, plumule, jumlah polong berisi penuh dan bobot kering biji pertanaman. Perlakuan terbaik adalah lama perendaman 6 jam (L3).

juga disampaikan kepada Dekan dan semua pihak yang membantu dalam terlaksananya penelitian ini.
Tanam Terhadap Kecepatan Perkecambahan Biji Kacang

\section{DAFTAR PUSTAKA}

Anonim. 2013. Pengaruh Berbagai Media
Hijau. http://zyhe.wordpress.com, diakses tanggal 24 April 2016.


Arief, M., Tariq, M., Khan, M.U dan Munir, I. 2010. Effect of Seed Priming on Growth Parameters of Soybean. J. Bot, 43 (4) : 28032812.

Girolamo, G. D and L. Barbanti. 2012. Treatment Conditions and Biochemical Processes Influencing Seed Priming Effectiveness. Italian Journal of Agronomy, 25(7) : 178-188.

Munawar, A. 2010. Kesuburan Tanah dan Nutrisi Tanaman. Bogor : IPB Press.

Nurmauli dan Y. Nurmiaty. 2010. Studi Metode Invigorasi pada Viabilitas Dua Lot Benih Kedelai yang Telah Disimpan Selama Sembilan Bulan. Jurnal llmu Pertanian Indonesia. 15(1):20-24.

Padjar. 2010. Kedelai Setelah Satu Dekade.

http://majalah.tempointeraktif. com/id/arsip/2010/03/29/EB/mbm, diakses 23 April 2016.

Purwanti Setyastuti. 2004. Kajian Suhu Ruang Terhadap Kualitas Benih Kedelai Hitam dan Kuning. Jurnal Ilmu Pertanian.,11(1):22-23.
Ruliyansyah, A. 2011. Peningkatan Performansi Benih Kacangan dengan Perlakuan Invigorasi. Jurnal Perkebunan dan Lahan Tropika, 1 (1) : 13-18.

Rusmin, D. 2007. Peningkatkan Viabilitas Benih Jambu Mete (Anacardium occidentale L.) Melalui Invigorasi. Jurnal Perkembangan Teknologi Tanaman Rempah dan Obat, 19 (1) : 56-63.

Sivasubramaniam, K., R. Geetha, K. Sujatha, K. Raja, A. Sripunitha and R. Selvarani. 2011. Seed Priming: Triumphs and Tribulation. Madras Agricultural Journal, 98 : 197-209.

Surtinah, S., Susi, N., dan Endriani, E. 2018. Meningkatkan Daya Berkecambah Benih Seledri (Apium Graviolens) Dengan Invigorasi. Jurnal BiBieT, 3(1): 33-39.

Zulkarnaeni. 2010. Dasar-Dasar Hortikultura. Jakarta : Bumi Aksara. 